TecnoLógicas

ISSN-p 0123-7799

ISSN-e 2256-5337

Vol. 23, No. 49, pp. 33-51

Sep-dic de 2020

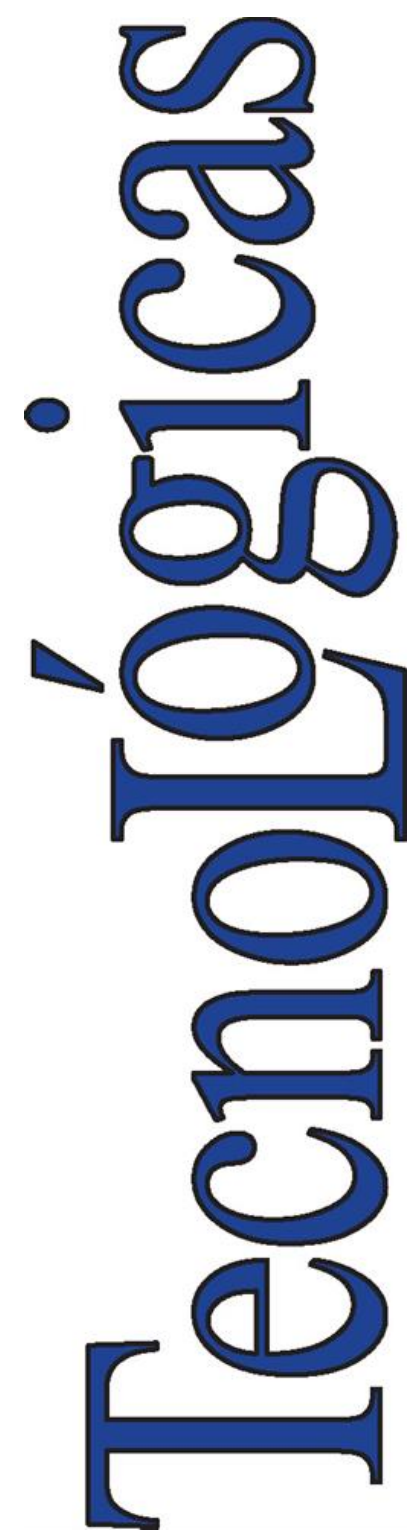

(C) Instituto Tecnológico Metropolitano Este trabajo está licenciado bajo una Licencia Internacional Creative Commons Atribución (CC BY-NC-SA)

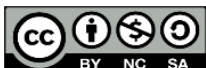

Artículo de Revisión/Review Article

\section{Characterization of Electrospun Silk Fibroin Scaffolds for Bone Tissue Engineering: A Review}

\section{Caracterización de andamios de seda fibroína electrohilados para ingeniería de tejidos óseo: una revisión}

\author{
Mónica Liliana Mejía-Suaza (D) \\ Maria Elena Moncada (D2, \\ Claudia Patricia Ossa-Orozco $\mathbb{D}_{3}$
}

Recibido: 2 de diciembre de 2019

Aceptado: 18 de mayo de 2020

Cómo citar / How to cite

M. L. Mejía-Suaza, M. E. Moncada, C. P. Ossa-Orozco, "Characterization of Electrospun Silk Fibroin Scaffolds for Bone Tissue Engineering: A Review", TecnoLógicas, vol. 23, no. 49, pp. 33-51, 2020. https://doi.org/10.22430/22565337.1573

1 MSc in Biomedical Engineering, Faculty of Engineering, Instituto Tecnológico Metropolitano, monicamejia2111@gmail.com

$2 \mathrm{PhD}$ in Electrical Engineering, Faculty of Engineering, Instituto Tecnológico Metropolitano, mariamoncada@itm.edu.co

$3 \mathrm{PhD}$ in Metallurgical and Materials Engineering, Biomaterials Research Group, Bioengineering Program, Faculty of Engineering, Universidad de Antioquia, claudia.ossa@udea.edu.co 


\section{Abstract}

Silk Fibroin (SF) is a natural polymer obtained from the Bombyx mori silkworm. It has been used in bone tissue engineering thanks to its favorable biocompatibility, adhesion, low biodegradability, and tensile strength properties. Electrospinning is a technique to develop nanofibers. It uses high voltages to convert polymer solutions into porous nanostructured scaffolds with a good ratio between superficial area and volume. In this paper, we examine the effect of the electrospinning parameters on fiber morphology once the spun fibers have been treated. In addition, we present different physicochemical characterizations of electrospun SF scaffolds such as their morphology (via Scanning Electron MicroscopicSEM-), crystalline structure (via Fourier Transform Infrared-FTIR-spectroscopy and XRay Diffraction-XRD-), thermal characteristics (via Differential Scanning CalorimetryDSC-and Thermogravimetric Analysis-TGA-), and mechanical properties (tensile strength). Finally, we discuss the potential applications and impacts of electrospun SF in bone tissue engineering and future research trends.

\section{Keywords}

Silk fibroin, electrospinning characterization, bone tissue engineering.

\section{Resumen}

La fibroína de seda es un polímero natural obtenido del gusano Bombyx mori, que se ha utilizado en la ingeniería de tejidos óseos debido a sus propiedades de biocompatibilidad, adhesión, baja biodegradabilidad y resistencia a la tracción. El electrohilado es una técnica para desarrollar nanofibras, utiliza altos voltajes para convertir soluciones de polímeros en andamios nanoestructurados, con porosidad, buena relación entre el área superficial y el volumen. En esta revisión examinamos los parámetros de electrohilado en la morfología de la fibra, después del tratamiento de las fibras hiladas. Además, presentamos diferentes caracterizaciones fisicoquímicas de andamios de fibroína de seda electrohilada como morfológico (microscopia electrónica de barrido - SEM), estructura cristalina (espectroscopia de transformada infrarroja de Fourier - FTIR, difracción de rayos X- XRD), análisis térmico (calorimetría diferencial de barrido- DSC, análisis termogravimétrico - TGA) y propiedades mecánicas (resistencia a la tracción). Finalmente, presentamos una discusión concerniente a las potenciales aplicaciones e impactos de la fibroína de seda electrohilada en la ingeniería del tejido óseo y las tendencias futuras.

\section{Palabras clave}

Fibroína de seda, caracterización de electrospinning, ingeniería de tejidos óseo. 


\section{INTRODUCTION}

\subsection{Bone repair}

Bone repair is a complex process consisting of a cascade of osteogenic events. After an injury, different cell types, signaling molecules, and matrix proteins work together to repair the bone defect. However, the natural mechanism of bone healing is inadequate for large bone defects which cannot be treated with routine clinical procedures [1].

Bone defect reconstruction has conventionally been based on the use of autologous bone grafts or autografts. They are considered the gold standard and the most effective method for bone healing and regeneration because they provide osteogenic cells and essential osteoinductive growth factors. In addition, they offer relatively better chances of success, as they do not cause an immune response. However, some of their limitations include the need to remove bone from another part of the body, an increased morbidity of the donor site, costs associated with surgeries, and a longer recovery time [2].

Allografts (tissues extracted from another person's body) and xenografts (tissues extracted from animals) are also widely employed in bone repair.

Nevertheless, they may induce immunological rejection and transmission of pathogens from the donor to the host [3]. Some of the materials commonly used as substitutes for bone grafts include metals and ceramics. Although metals offer immediate mechanical support at the defect site, they poorly integrate with the host tissue and can fail due to fatigue loading. Ceramics are brittle, have low tensile strength, and cannot be used in defects located in areas subjected to torsion, bending, or significant shear stress [4].

\subsection{Bone tissue engineering}

To overcome the limitations of current graft procedures, new alternative therapies have been introduced, such as bone tissue engineering. This approach provides a reliable, affordable, and physiologically acceptable solution for bone regeneration. The term "tissue engineering" proposed in 1993 refers to a field that combines materials engineering with biology to produce ThreeDimensional (3D) scaffolds that mimic the Extracellular Matrix (EMC) and the functionality of natural tissue [1], [2].

Bone Tissue Engineering (BTE) has been regarded as an alternative to regenerate critical bone defects. It aims to create $3 \mathrm{D}$ bone tissues, as from graft substitutes or scaffolds, using in vitro seeded cells (e.g., Mesenchymal Stem Cells-MSCs-and Endothelial Progenitor Cells-EPCs-), as well as bioactive molecules, such as growth factors [1], [2].

\subsection{Bone tissue requirements}

For the bone system, scaffolding is required to enable a much firmer structural support (i.e., mechanical resistance) due to the physical loads that bones must support. Other relevant requirements for BTE scaffolds include:

Biocompatibility [5]-[7]

Bioabsorbability [6]

Slow biodegradability [5]

Angiogenesis [6]

Porosity and microarchitecture that mimic the extracellular matrix (EMC) [5], [8]-[11]

Osteoconductivity and osteoinductivity [12]-[17]

Surface properties [8], [18]-[20]

Suitable mechanical strength [8]

Adhesion [8], [21]-[23]

In BTE, different techniques have been implemented to develop scaffolds, including gas foaming, fiber meshes sintering, solvent casting, polymerization 
in solution, porogen leaching method, freeze-drying, 3D printing, and electrospinning. This latter method has become popular because it mimics the nanoscale properties of the native EMC, thus promoting cell growth.

Silk Fibroin (SF) has been commonly employed in wound dressings and drug delivery applications. However, its use in bone tissue engineering has been little explored.

This paper presents an overview of the potential use of SF with electrospinning for bone tissue regeneration, as well as the physicochemical characterizations of electrospun silk fibroin scaffolds such as their morphology (via Scanning Electron Microscopic-SEM-), crystalline structure (via Fourier Transform Infrared-FTIR—spectroscopy and X-Ray Diffraction-XRD-), thermal characteristics (via Differential Scanning Calorimetry-DSC-and

Thermogravimetric Analysis -TGA-), and mechanical properties (tensile strength). In addition, we discuss the potential applications and impacts of electrospun silk fibroin in bone tissue engineering and future research trends.

\section{ELECTROSPINNING}

With this technique, nanostructured membranes containing nanofibers with diameters below $500 \mathrm{~nm}$ are produced.

Moreover, it serves to fabricate scaffolds using micro/nanofibers. Their high porosity, morphology similar to that of a natural EMC, high surface area to volume ratio, and small interconnected fibrous pores promote cell adhesion, migration, and proliferation, thus creating new bone tissue.

Electrospinning has proven to be simple, versatile, cost-effective, and reproducible [24]. It uses an electric field to convert polymer solutions into fiber forms [25]. This process consists of three main components: (1) a high voltage source, which guarantees a continuous electric field with a positive and a negative polarity; (2) an infusion pump, adjusted to control the feed rate of the polymer solution contained in a syringe with an inner capillary diameter of $0.1-1 \mathrm{~mm}$ or needle; and (3) a metallic collector (usually a stationary aluminum plate or a rotating cylinder) where the resulting fibers are deposited [26].

To achieve fiber deposition, the solution must be exposed to a voltage between 10 and $50 \mathrm{kV}$. This voltage is applied between a suspended drop of the polymer solution located at the tip of the needle nozzle and a grounded stationary or rotating metallic collector that serves as a counter-electrode. Electrospinning is performed by controlling the temperature and humidity.

When the applied electric field exceeds the surface tension of the droplet, a conical shape (Taylor's cone) is formed, and a charged jet of the polymer solution is ejected during the elongation and instability phase. Such jet is drawn by the electric field to the collector located between 10 and $25 \mathrm{~cm}$ away from the needle. The jet becomes long and stable, forming thin filaments, while the solvent evaporates quickly. Finally, the TwoDimensional (2D) nanofibers are deposited in the grounded collector; or the 3D nanofibers, in the methanol colloidal solution [25].

Although the shape of electrospun nanostructured membranes has been limited to a 2D sheet form, recent works have proposed the construction of spongelike 3D scaffolds. This 3D scaffolds have proven to be highly efficient for cell attachment during the former stages of cell culture. This, along with their highly porous structure, is beneficial for the exchange of nutrients or gases between cells [27].

The electrospinning process is influenced by several factors, including the 
solution's properties (polymer concentration, viscosity, electrical conductivity, surface tension, and dielectric characteristics), processing parameters (voltage, flow rate, distance between the needle and the collector), and environmental conditions (humidity and temperature). In order to avoid the presence of droplet defects and allow a proper fiber formation and structuring, such factors should be controlled [24], [28].

\subsection{Silk Fibroin}

Silk Fibroin (SF) is a natural fibrous protein that is extracted from the cocoon of silkworms. It has been employed to produce a variety of biomaterials (e.g., gels, sponges, membranes, and films) for biomedical applications [29]-[34].

Its use has been explored in drug delivery and tissue engineering. For instance, it has been employed as a cell culture substrate due to its suitable biocompatibility, slow biodegradability rate, microbial resistance, low inflammatory response, good cellular response, and good oxygen and water vapor permeability and moisture [30].

However, SF is brittle, so it can easily break in a dry state, but combining it with other polymers can improve its mechanical properties [35]. Moreover, SF nanofibers have low osteoinductive properties; hence, a wide range of osteogenic agents have been incorporated to improve cell-matrix interactions and osteogenicity, making it a suitable biomaterial for bone tissue engineering [35].

The fibrous structure of SF is similar to that of type I collagen (Col I). Its amorphous bonds between the $\beta$ sheets serve as sites for the deposition of hydroxyapatite nanocrystals because they can mimic the anionic structure of NonCollagenous Proteins (NCPs). The inherent integrin-binding tripeptide, ArgGly-Asp (RGD), present in the amino acids enables firm cell adhesion in fibroin obtained from the cocoons of non-Morera species (Bombyx mori) (e.g., Tussak or Samia Cynthia ricini) [30]. The maximum tensile strength of fibroin extracted from Bombyx mori ranges from 300 to $740 \mathrm{MPa}$.

In addition, such fibroin has a higher resistance to breaking than synthetic fibers, such as Kevlar [2]. These two factors are important values for bone tissue applications.

Fibroin is extracted by cutting the cocoons into small pieces which are dissolved in distilled water and $0.2 \%$ sodium carbonate $\left(\mathrm{Na}_{2} \mathrm{CO}_{3}\right)$ at a temperature of $80{ }^{\circ} \mathrm{C}$ [36]. Then, they are rinsed with distilled water to remove impurities. The degummed SF fibers are dissolved in a ternary solvent system consisting of calcium chloride $\left(\mathrm{CaCl}_{2}\right)$ / distilled water $\left(\mathrm{H}_{2} \mathrm{O}\right)$ / ethanol $\left(\mathrm{CH}_{3} \mathrm{CH}_{2} \mathrm{OH}\right)$ (molar ratio $\left.=1: 8: 2\right)$ or in 9.3 $\mathrm{M}$ lithium bromide $(\mathrm{LiBr})$ at $60^{\circ} \mathrm{C}$ for 1 hour. This solution is dialyzed using tubular cellulose membrane (12 kDa, Sigma Aldrich) (MWCO: 12,000-14,000 Da) with distilled water at room temperature for 3 days to eliminate salts $\left(\mathrm{CaCl}_{2}\right)$ or to remove the remainder $\mathrm{LiBr}$ and then stored in a refrigerator at $4{ }^{\circ} \mathrm{C}$ for its conservation [37].

The use of caustic and organic solvents potentially compromises the biocompatibility and mechanical properties of silk fibroin fibers [38].

Therefore, solvents for dissolving silk fibroin should not interfere with the biocompatibility of the processed material when exposed to cells in vitro or in vivo [39]. The secondary structure of silk fibroin ( $\beta$-sheets) in the electrospun fibers must be maintained to achieve optimal mechanical properties [39]. Employing forced winding directly from silkworms or a hot aqueous ammonium sulfate coagulation bath, produces fibers with exceptional mechanical properties. The most desirable approach would be to exactly mimic the natural process, where water is the only solvent [40]. 


\subsection{Silk fibroin solution}

In general, high concentrations of silk fibroin or adding other polymers, such as Polyethylene Oxide (PEO), is required to generate silk fibroin nanofibers from a silk fibroin solution during electrospinning [41]. The following solvents have been widely used to prepare silk fibroin solutions for electrospinning:

Fibroin lyophilized in $98 \%$ formic acid [27], [39], [41]-[48] at concentrations from $5 \%$ wt to $20 \%$ wt; distilled water with Polyethylene Glycol (PEG) [40], [49]-[51] at concentrations of $10 \%$ wt PEG and 30$40 \%$ wt SF; or PEO [38], [39], [50]-[56] to achieve electrospinning at concentrations of $5 \%$ wt PEO and $9 \%$ wt SF. Silk fibroin lyophilized in formic acid produces thinner nanofibers than PEO. When compared to distilled water, formic acid is found to increase the intramolecular hydrogen bond by enhancing $\beta$-sheet crystallization and minimizing the hydrodynamic radius of fibroin. However, the use of formic acid, for instance, could lead to cytotoxicity and an immune response [57]; PEO may affect the mechanical properties and biocompatibility of the fibers [39]; and Hexafluoroacetone (HFA) hydrate [58], at concentrations from $2 \% \mathrm{wt}$ to $10 \% \mathrm{wt}$, could also compromise the biocompatibility of the fibers [39].

\subsection{Electrospinning parameters for fibroin}

Some studies have defined the following electrospinning parameters for silk fibroin: flow rate of $0.5 \mathrm{~mL} / \mathrm{h}$ [59], voltage of $15 \mathrm{kV}$ [53], [59], and a distance of $15 \mathrm{~cm}$ between the needle and the collector [60]. The most widely employed collectors are rotating drum, flat sheet of aluminum foil, and spinneret submerged in a methanol bath. Electrospinning is carried out at room temperature and a relative humidity of $40-60 \%$. To obtain the membranes, subsequent treatments have also been reported, including crosslinking, which induces structural conformational changes and crystallization of amorphous sheets into $\beta$ sheets.

\section{PHYSICOCHEMICAL CHARACTERIZATION OF SILK FIBROIN NANOFIBERS}

\subsection{Morphological analysis - Scanning Electron Microscopy (SEM)}

The morphology of electrospun SF nanofibers was analyzed using SEM at a temperature of $20{ }^{\circ} \mathrm{C}$ and a relative humidity of $60 \%$. The samples were mounted on a copper plate and cathodically sprayed with a 20-30-nmthick gold layer before obtaining the micrographs [41]. The acceleration voltage was set between 10 and $20 \mathrm{kV}$, and approximately 50 random fibers were measured to determine the average fiber diameter and its distribution by means of the following image analysis software: Image J [50], [54], [61], [62], Inner View TM [45], and SemAphore 4.0 [42].

The higher the concentration of fibroin, the larger the average diameter of the nanofibers: $6 \% \mathrm{wt}$ : $53.9 \mathrm{~nm}$ [41], while $33 \%$ wt: 1602 nm [38]. Fig. 1, shows the increased diameter of the nanofibers of pure SF (from $146.58 \pm 36.09 \mathrm{~nm}$ to 262.21 $\pm 77.55 \mathrm{~nm})$ due to coagulation time with methanol. This might be caused by an increase in the composition of the $\beta$-sheet, which, in turn, leads to a higher interaction between the chains and, thus, the formation of larger fibers [38].

Treatment with methanol induces a higher dispersion in the average diameter of the nanofibers, as observed in the histograms. 

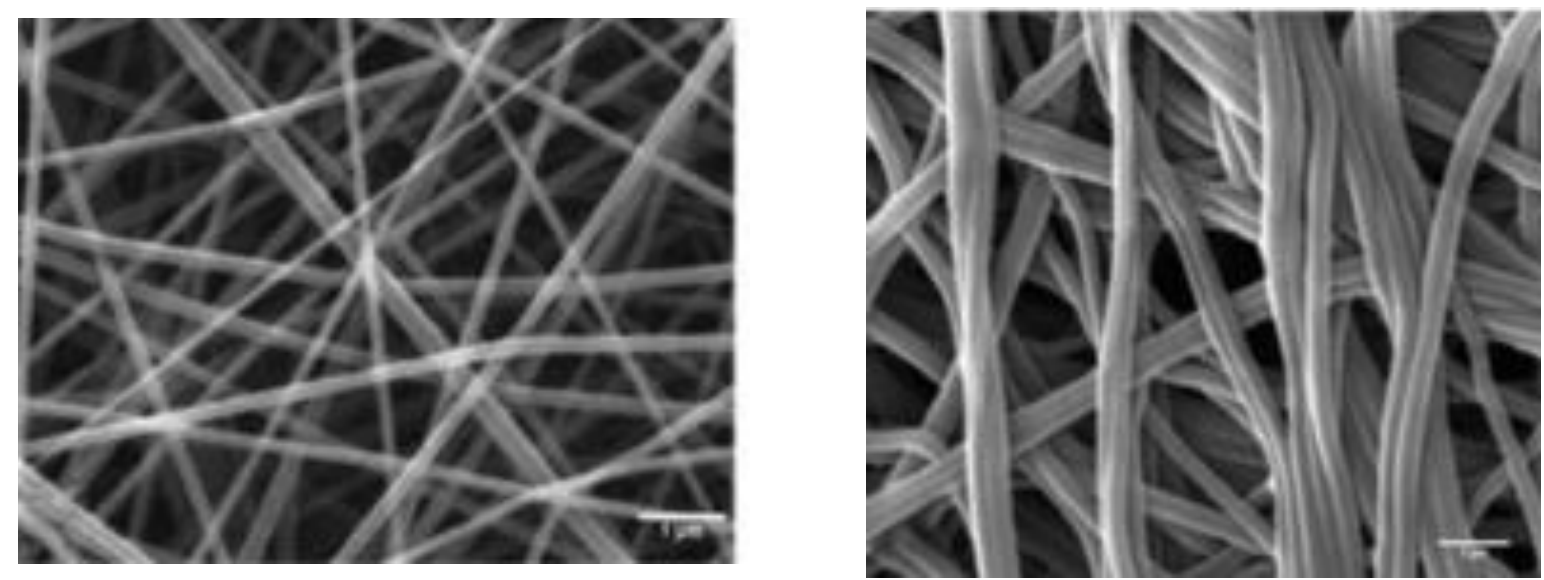

Fig. 1. Silk Fibroin (SF) nanofibers at concentrations of 13\% wt. (a) Pure SF $146.58 \pm 36.09 \mathrm{~nm}$,

(b) Cross-linked SF in methanol bath $262.21 \pm 77.55 \mathrm{~nm}$. Source: [47].

\subsection{Crystalline structure - Fourier Transform infrared (FIR) spectroscopy}

FTIR spectroscopy was used to determine the chemical composition of silk fibroin nanofibers via an Attenuated Total Reflectance (ATR) accessory. For each measurement, 128 scans were coded with a resolution of $4 \mathrm{~cm}^{-1}$, with a spectral region ranging from 400 to $4000 \mathrm{~cm}^{-1}$ [41], [47], [50], [57], [63], [64]. Curve-fitting and deconvolution methods were applied to the most informative fibroin region of amide I and amide II extending from 1750 to 1450 $\mathrm{cm}^{-1}$ and associated with the secondary structural conformation of $\alpha$-helix and $\beta$ sheet. In addition, the spectra were analyzed using OriginPro [45], [65], PeakFit v4.12 [66], [67], and Spectrum [64].

FTIR spectroscopy was employed to examine the conformational changes that occur during the electrospinning process.

The a-helix showed strong absorption bands at $1656 \mathrm{~cm}^{-1}$ (amide I) $(\mathrm{C}=\mathrm{O}$ stretching vibrations), $1540 \mathrm{~cm}^{-1}$ (amide II) (secondary $\mathrm{N}-\mathrm{H}$ bending), and $1230 \mathrm{~cm}^{-1}$ (amide III) (C-N stretching vibrations and $\mathrm{N}-\mathrm{H}$ bending). The estimated percentage of $\beta$-sheets was $29.28 \%$. Both crystalline and amorphous structures coexisted in different proportions in the silk fibroin samples, and a greater presence of B-sheet structures in the nanofibers was observed [43], [57], [65]-[68]. The absorption bands moved slightly after treatment with methanol or ethanol to $1626 \mathrm{~cm}^{-1}$ (amide I), $1523 \mathrm{~cm}^{-1}$ (amide II), and $1260 \mathrm{~cm}^{-1}$ (amide III), which indicates that the structure changed to crystalline $\beta$-sheet monoclinic antiparallel chains pleated in the electrospun nanofibers [50], [54], [63].

This is a critical factor for the low in vivo biodegradability of silk-based materials. However, their crystallinity is very low compared to that of the raw silk fiber [41], [45], [47], [64]. Fig. 2 presents the FTIR spectra.

\subsection{Crystalline structure - X-Ray Diffraction (XRD)}

The crystal structure of silk fibroin nanofibers was studied using an X-ray diffractometer with a LynxEye detector [67], a $\mathrm{CuKa}$ radiation source (wavelength $\lambda=0.1541 \mathrm{~nm}$ ) operating at $40 \mathrm{kV}$ and 40 $\mathrm{mA}$ over diffraction angles measured from $2 \theta=0-40^{\circ}$, and an $X^{\prime}$ celerator counter [49], [69] at a scanning rate of $0.015 \%$ [67], $0.040 \%$ [49], $0.048 \%$ [70]. These parameters serve to obtain an X-ray diffractogram [71].The crystallinity of the silk fibroin nanofibers and the variation in the percentage of $\beta$-sheet content corresponding to the crystal structure due to enzymatic degradation were determined 
[49]. The database of the International Centre for Diffraction Data (ICDD) was employed to identify the composition of the phase [64].

Fig. 3 shows the XRD analyzes of the silk fibroin nanofiber membranes that were cross-linked in methanol or ethanolsolvents that induce crystallization. In such figure, diffraction peaks at $2 \theta=14.51$ $\circ$, as well as less intense peaks at $2 \theta=$ $20.74^{\circ}$ and $2 \theta=23.9^{\circ}$, are observed.

These peaks are characteristic of the silk II structure and confirm the existence of B-sheet structures [49], [67], [69] of 10.1 $\AA$ ([100+ $010+001]$ reticular plane), $4.4 \AA$ $([200+020]$ reticular plane $)$, and $3.7 \AA$ ([201] reticular plane) of diameter. In addition, these peaks indicate the coexistence of crystalline and amorphous structures in the electrospun of silk fibroin nanofibers although they were treated with methanol [69]. The estimated percentage of crystallinity of the pure silk fibroin membrane was $22.24 \%$ [47]; its increase (to $35.54 \%$ ) is attributed to methanol [47], [66], [70], [72].

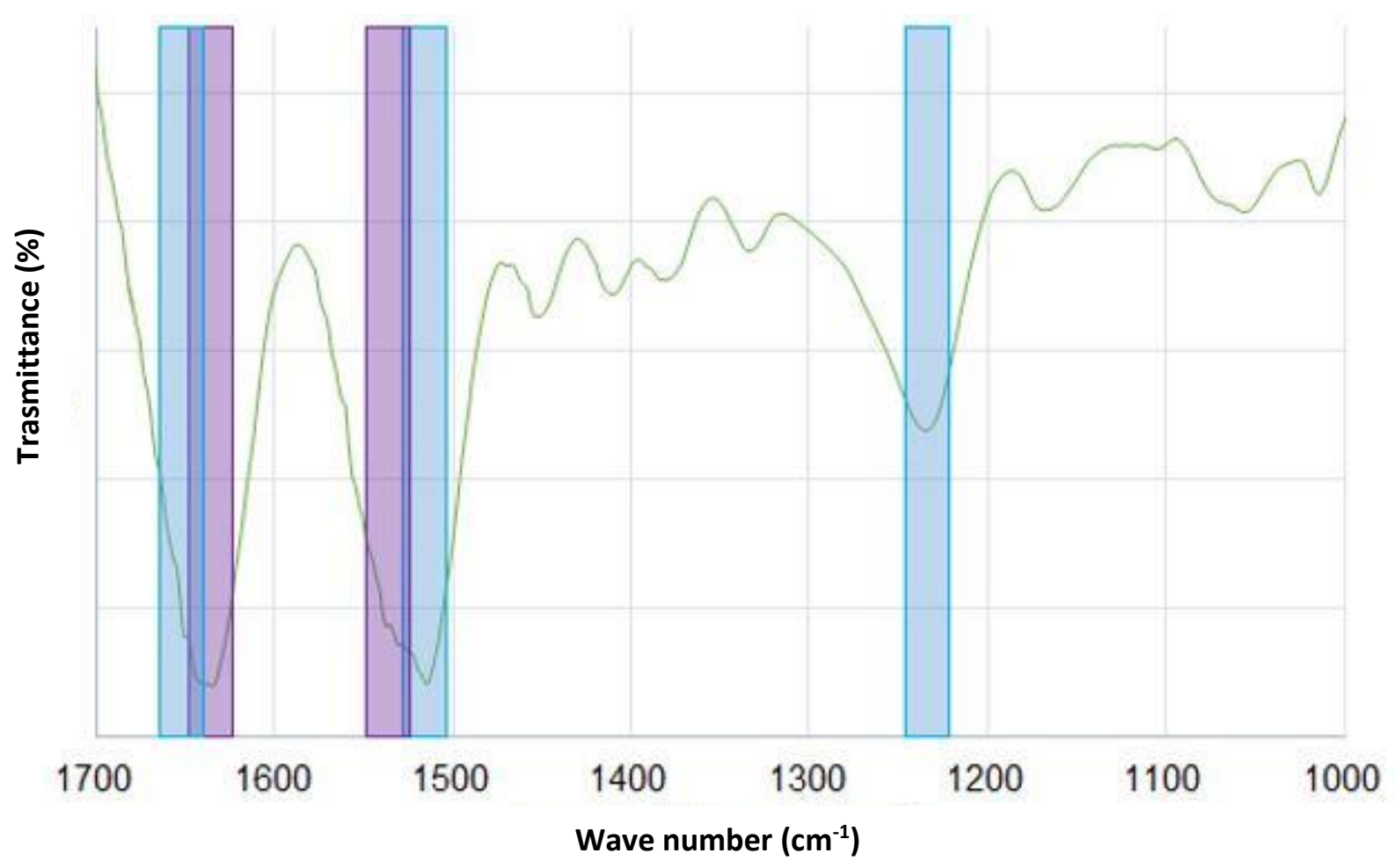

Fig. 2. FTIR spectra of electrospun silk nanofiber mat Source: [73]. 


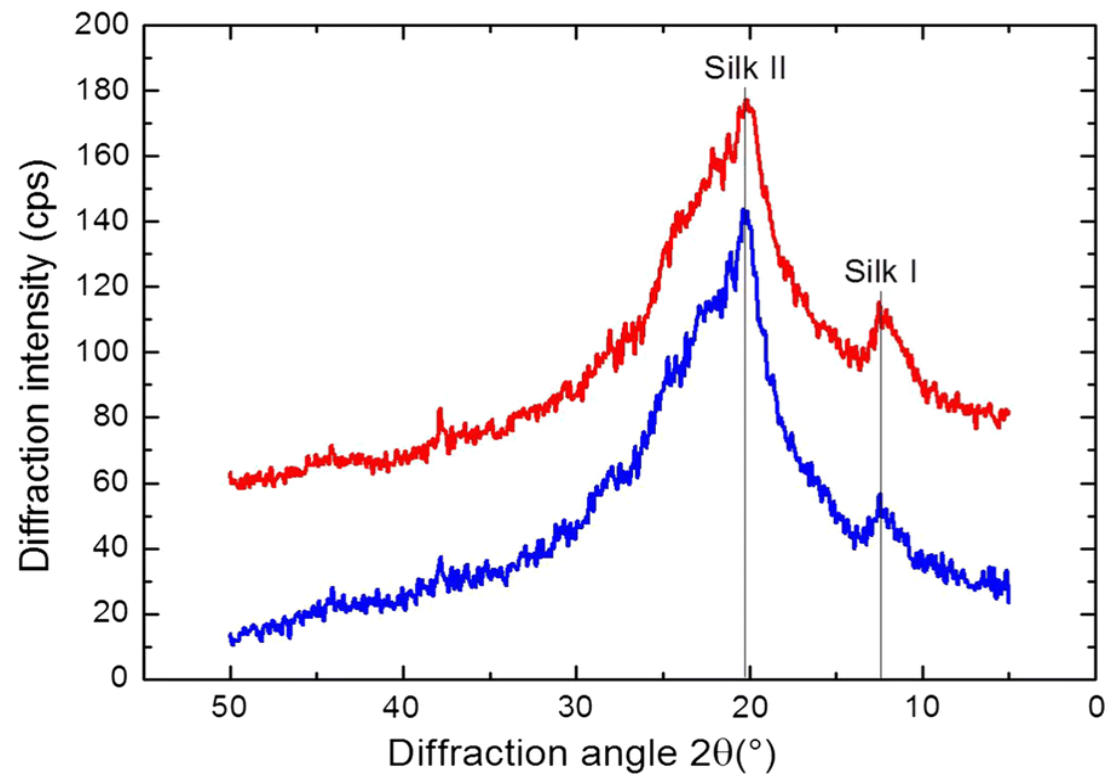

Fig. 3. XRD of electrospun cross-linked silk fibroin scaffold Source: [67].

\subsection{Thermal analysis - Differential Scanning Calorimetry (DSC)}

Samples weighing $5 \mathrm{mg}$ were encapsulated in a sealed aluminum tray and heated in a differential scanning calorimeter under a dry nitrogen gas flow of $50-100 \mathrm{~mL} / \mathrm{min}$ and at a heating rate of $10{ }^{\circ} \mathrm{C} / \mathrm{min}$ and temperature ranges of 30 $300^{\circ} \mathrm{C}$.

Fig. 4 shows the DSC thermogram of silk fibroin. According to this figure, there is an endothermic peak at approximately $80-100{ }^{\circ} \mathrm{C}$, which is associated with water evaporation. The appearance of another endothermic peak at $180{ }^{\circ} \mathrm{C}$ for the compounds is caused by the start of the crystallization process within the silk fibroin (silk I and silk II). The occurrence of another peak at $278{ }^{\circ} \mathrm{C}$ is attributed to the thermal degradation of amorphous silk fibroin, a behavior related to the fact that unstable noncrystalline structures can be transformed into crystalline structures of the B-sheet [65], [68], [73]-[76]. Finally, the strongest peak around $360{ }^{\circ} \mathrm{C}$ is due to the melting and decomposition of the silk fibroin, which corresponds to its semicrystallinity [30].

\subsection{Thermal analysis - Thermogravimetric Analysis (TGA)}

Prior to this analysis, all samples were stored in a container with silica gel to eliminate the effect of water. The thermal properties of $2 \mathrm{mg}$ of each sample were characterized using a thermogravimetric analyzer under a nitrogen atmosphere with a gas flow of $20-100 \mathrm{~mL} / \mathrm{min}$ - Then, they were heated at temperature ranges of 25-1800 ${ }^{\circ} \mathrm{C}$ and at a heating rate of 10 ${ }^{\circ} \mathrm{C} / \mathrm{min}$. Measurements were determined based on temperature increase in order to evaluate the thermal degradation behavior of the samples.

The curves were divided into two regions. Region I recorded a weight loss of around $7 \%$ (attributed to water evaporation) at $100{ }^{\circ} \mathrm{C}$ [62] with respect to the original sample, while region II exhibited a weight loss of $20 \%$ at $270-370$ ${ }^{\circ} \mathrm{C}$. This is linked to the thermal degradation of silk fibroin, which is, in turn, associated with the decomposition of peptide bonds of amides [65].

Fig. 5 illustrates the weight variation of the silk fibroin nanofibers. When temperature increased to $350{ }^{\circ} \mathrm{C}$, their original weight reduced approximately by 
$50 \%$. At $600{ }^{\circ} \mathrm{C}$, their weight residue was around $9 \%$ and $11 \%$ [77]. Their thermal degradation was significantly higher compared to that of composite nanofibers (97.246\% for pure fibroin and $92.268 \%$ for silk fibroin / reduced Graphene Oxide
RGO nanofibers) [78]. The silk fibroin scaffold and Hydroxyapatite (HA) exhibited better thermal stability, with a weight loss of approximately $30-35 \%$ at $375^{\circ} \mathrm{C}$ [62], [79].

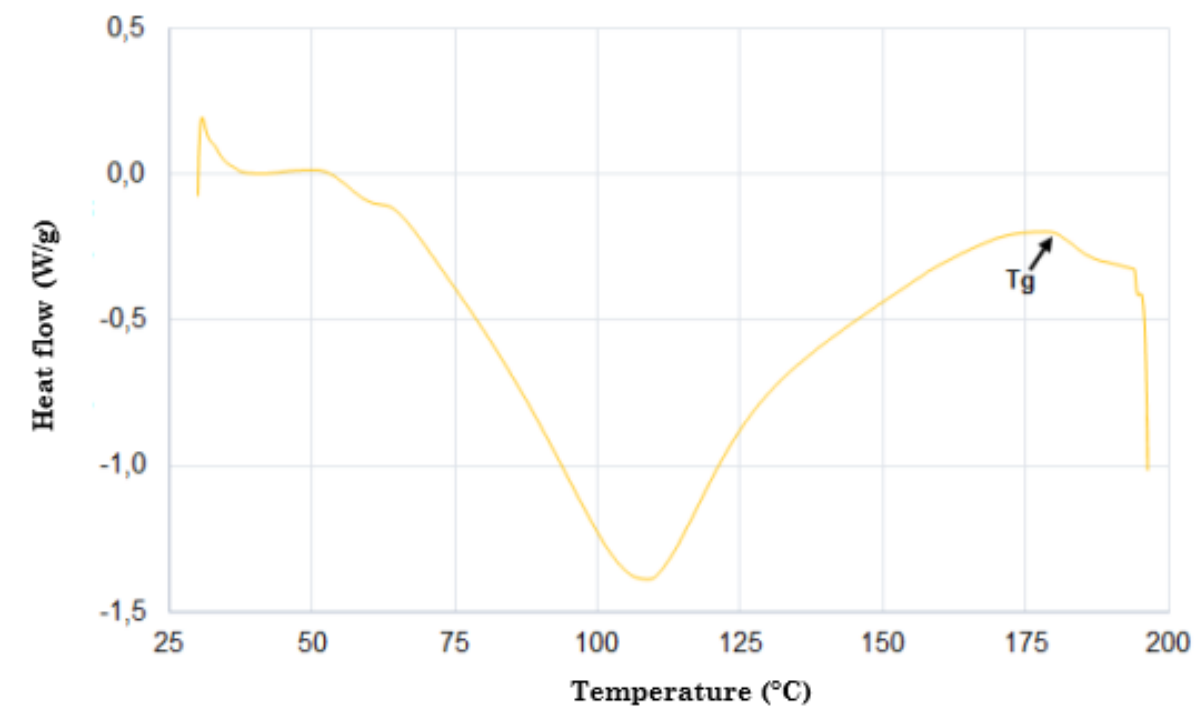

Fig. 4. DSC analysis of silk fibroin scaffold. Source: [49].

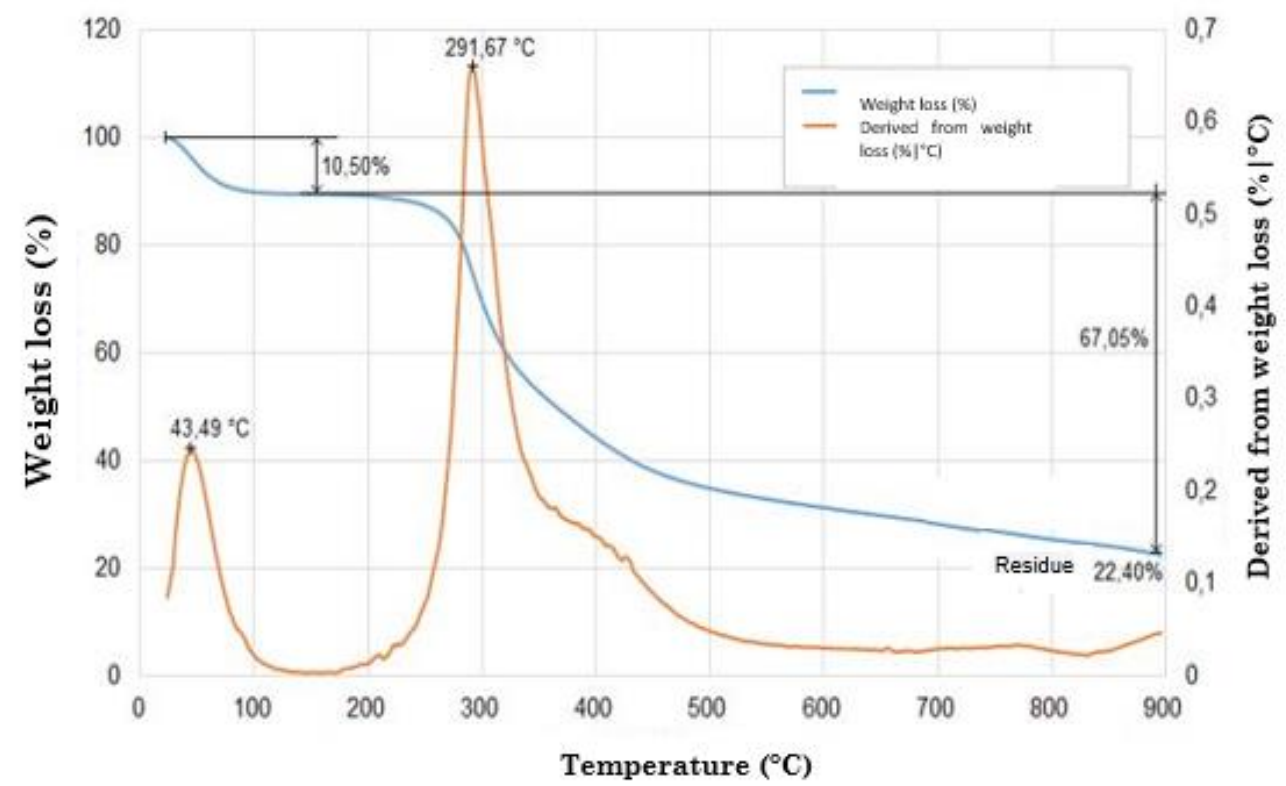

Fig. 5. Thermograms of pure SF scaffold. Source: [80]. 
This analysis shows that scaffold treated with ethanol can better withstand higher temperatures than untreated samples because treatment with ethanol increases the structural crystallinity of the $\beta$-sheet form of silk fibroin, making it more thermally stable [49], [70], [71], [81], [82].

\subsection{Mechanical properties - Tensile Strength (TS)}

This procedure consists in the application of longitudinal force to a rectangular test piece, in accordance with the ASTM D882 or ASTM D638 type V standards. Tissue engineering scaffolds must possess a high tensile strength which is an essential factor since it supports cell growth in vitro and tissue organization. In addition, they must have the desired elastic modulus to facilitate the osteogenic differentiation of the cells [49]. Also, the alignment of silk fibroin nanofibers can also improve the required mechanical properties. Fig. 6 depicts the stress-strain curve of a electrospun randomly oriented silk fibroin scaffold (concentration of $15 \%$ wt) with a maximum tensile strength of $7.25 \mathrm{MPa}$ and a Young's modulus of 515 $\mathrm{MPa}$ [43].

This mechanical property allows the successful retention of Mesenchymal Stem Cells (MSCs), an aspect of great importance for tissue engineering because scaffolds should ideally maintain their shape during implantation and withstand mechanical loads after implantation [49].

The samples were carefully removed from the foil and cut into strips with the following sizes (length $\mathrm{x}$ width): $3 \mathrm{~mm} \times 3$ $\mathrm{mm}$ [83]; $0.5 \mathrm{~cm} \times 4 \mathrm{~cm}$ [43], [53], [56]; 50 $\mathrm{mm} \times 5 \mathrm{~mm}$ [41], [69]; and $50 \mathrm{~mm} \times 12 \mathrm{~mm}$ with a thickness of $0.30 \mathrm{~mm} \pm 0.01 \mathrm{~mm}$ [49]; $30 \mathrm{~mm} \times 10 \mathrm{~mm}$ with a thickness of $0.8 \mathrm{~mm}$ [52], [64]; and $10 \mathrm{~mm} \times 50 \mathrm{~mm}$ [66], [70], [74], [78] with a thickness of $0,16 \mathrm{~mm} \pm 0,01 \mathrm{~mm}$ [70], $(60 \sim 110 \mu \mathrm{m})$ [66], (170-370 nm) [74].

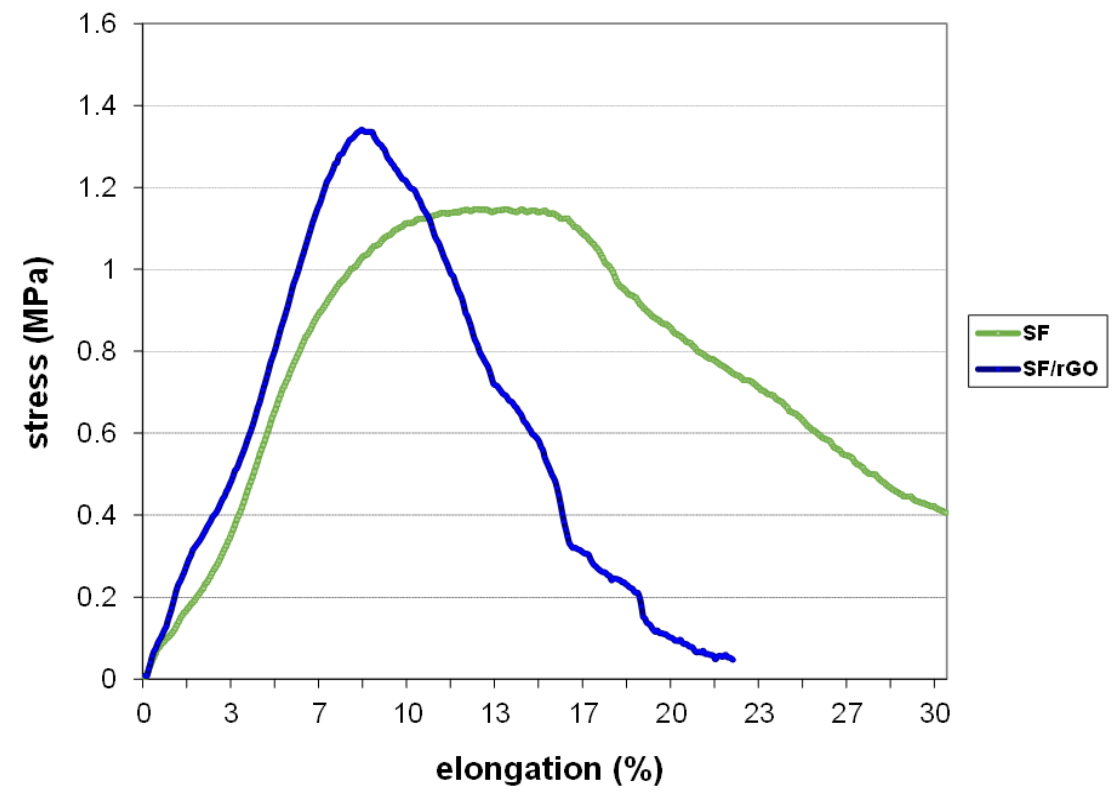

Fig. 6. Stress-strain curve of electrospun randomly oriented silk scaffold at a concentration of $15 \%$ wt Source: [43]. 
Then, they were pasted on a square paper template and tested in a universal machine at room temperature and a relative humidity of $65 \%$ using a load cell of $10 \mathrm{~N}$ at a constant extension rate of 20 $\mathrm{mm} / \mathrm{min}$ [43], [49], [60], [74], [83], [84]; 5 $\mathrm{mm} / \mathrm{min}$ [69], [76]; $10 \mathrm{~mm} / \mathrm{min}[[53]$, [66], [74]; and $50 \mathrm{~mm} / \mathrm{min}$ [85]. The gauge length was $20 \mathrm{~mm}$ [66], [84]. The maximum tensile strength ( $\mathrm{MPa})$, Young's modulus $(\mathrm{MPa})$, and elongation percentage (\%) were determined based on the recorded force-elongation curve [37], [52], [53], [60], [64], [74], [76], [78], [84]-[86].

An average of five measurements was taken as the mean \pm standard deviation for each sample [41], [66].

The increased tensile strength of silk fibroin scaffolds treated with ethanol or methanol could be attributed to a higher fiber crystallinity. The crystalline structure of the $\beta$-sheets and the compactness of the scaffolds may be responsible for the reduced elongation at the time of failure [37], [70], [78]. The elongation at break decreased after the incorporation of the carbon nanotubes.

The composite nanofibers were less flexible compared to the pure silk fibroin nanofibers. However, it led to a higher maximum tensile strength and Young's modulus [86].

The tensile strength, the deformation percentage, and the Young's modulus increased with the increasing HA content up to $20 \%$ wt. Nevertheless, they decreased after that because the HA nanoparticles tend to aggregate when their density reaches a critical level. As a result, the fibers can turn discontinuous and brittle. Therefore, large quantities of HA could accelerate the breakage of the scaffolds during the tensile test [60], [74].

Silk fibroin membranes containing $0.5 \%$ wt of rGO treated with methanol showed higher values of percent strain, and those containing $3 \%$ wt reported an improved maximum fracture strength.
This latter is caused by the intermolecular forces formed between SF and graphene, which restricted the movement of the polymer chains [78].

The variations in silk fibroin concentrations from $0.8 \%$ wt to $41 \% \mathrm{wt}$ result in a higher maximum tensile strength (0,3-10 MPa), Young's modulus (0.3-515 $\mathrm{MPa})$, and deformation percentage (4\%-250\%). However, since the reported works used different measurements to test the specimens, the obtained results cannot be compared.

\section{CONCLUSIONS, DISCUSSION, AND FUTURE WORK}

Bone tissue engineering has a global impact on bone replacement and repair [10], which is why it constitutes one of the most active research areas in the field of tissue engineering. One of the greatest challenges in developing scaffolding materials concerns the suitable combination between properties such as mechanical strength and biodegradability.

In fact, these two latter behave antagonistically. Although, on the one hand, metals, apatites, and crystalline polymers show great mechanical strength, they are not biodegradable. On the other hand, amorphous apatites and bioglasses lack mechanical strength but exhibit good biodegradability. This evidently becomes a dilemma when developing new materials for bone tissue engineering [5].

Scaffolds must be able to adapt to the implantation site. Therefore, it is necessary to move from in vitro research to in vivo tests. In this regard, we highlight the efforts made in various studies to develop functional and affordable bone substitutes, for example, through the manufacture of polymeric or ceramic scaffolds using nuclear magnetic resonance images, considering the anatomy of the patient [10]. 
The solutions employed in silk fibroin electrospinning have an effect on the morphology of nanofibers. For instance, 98\% formic acid-the most widely used solvent-increases the crystallization of Bsheets and reduces their hydrodynamic properties [43].

For the successful development of scaffolds, the proper electrospinning parameters (e.g., flow rate and voltage) should be determined to generate fibers without droplet defects. Morphological characterization using SEM serves to analyze the average diameters of the nanofibers, which vary depending on the concentration of silk fibroin $(6 \%$ wt $=53.9$ $\mathrm{nm}$ and $33 \% \mathrm{wt}=1602 \mathrm{~nm})$. Moreover, scaffolds treated with ethanol and methanol exhibited a higher surface structural stability [70].

Porosity is another important factor in bone tissue engineering. The minimum required pore size is $\sim 100 \mu \mathrm{m}$ to enable cell migration and infiltration into the scaffold. Nevertheless, pore sizes greater than $300 \mu \mathrm{m}$ are recommended to allow new bone formation [87].

According to the XRD analysis conducted, the crystallinity of silk fibroin was not altered by the electrospinning process and the scaffold's treatment with ethanol [68].

The DSC thermogram showed three peaks. The first one corresponding to the vitreous transition temperature occurred at $80-100{ }^{\circ} \mathrm{C}$. The second one (melting temperature) at $180{ }^{\circ} \mathrm{C}$ was due to the start of the crystallization process within the silk fibroin. The third one at $278{ }^{\circ} \mathrm{C}$ was attributed to the beginning of the thermal degradation of the silk fibroin [30].

Furthermore, the TGA thermogram indicated that silk fibroin scaffold treated with ethanol or methanol is more thermally stable than pure silk fibroin because ethanol increases the structural crystallinity of the $\beta$-sheet form of silk fibroin. The decomposition temperature of both scaffolds (above $350{ }^{\circ} \mathrm{C}$ ) was higher than the temperature required by the retort $\left(120^{\circ} \mathrm{C}\right)$ to sterilize them [70].

Treatment with ethanol or methanol proven to enhance the tensile strength of scaffolds due to an increase in the fibers' crystallinity. The elongation at break was indicative of the flexibility of the materials and decreased after the incorporation of Multi-Walled Carbon Nanotubes (MWCNTs). The composite nanofibers were less flexible compared to the pure silk fibroin nanofibers. However, it led to a higher maximum tensile strength and Young's modulus [43], [86]. Current studies have used aligned electrospun fibers and postprocessing treatments (e.g., fiber drawing, annealing, and treatment with methanol) to improve the mechanical properties of nanofibers [43].

There is still much work to do to elucidate the influence of several factors on the electrospinning process due to the complex and interrelated effects of various parameters (solution viscosity, flow rate, voltage, distance from the needle to the collector). From this process, the challenge remains to obtain nanofibers with a uniform diameter and without droplets defects. Regarding the use of silk fibroin, it is expected to maintain batch-to-batch consistency given the varied sources of this material, as well as its processing.

Highly porous 3D scaffolds for bone tissue engineering not only provide better support for cell adhesion but also an ideal environment for cell migration and proliferation. In addition, the use of some additives, such as Hydroxyapatite (HA), Bone Morphogenetic Protein 2 (BMP-2), BTricalcium Phosphate ( $\beta$-TCP), and type I collagen), improve osteogenic potential, cell adhesion, stem cell differentiation, and tissue formation. Further work needs to be done to explore other alternative biomaterials and their combinations to enhance their properties.

Some studies have tested many polymer scaffolds in various cell types; however, they have been limited to 
preliminary qualitative in vitro biocompatibility analyzes. Thus, further work should focus on in vivo experiments.

So far, studies have been conducted in small animals, such as mice, demonstrating the osteogenic potential of silk fibroin scaffolds. Nevertheless, their biosecurity and practical effect in humans must be evaluated, since in vivo tests on animals do not yet sufficiently predict their performance in humans.

Likewise, further quantitative evaluations of the cellular function resulting from the topographic signals provided by scaffolds are needed. In addition, more work on silk fibroin scaffolds for bone tissue engineering would help to evaluate them through clinical trials and then commercialize them. This means that the translational benefits of silk fibroin scaffolds for tissue engineering is still a distant option for patients and victims.

The employment of electrospun scaffolds for the regeneration of large critical bone defects is a challenge that can only be overcome by combining $3 \mathrm{D}$ electrospinning with other techniques such as $3 \mathrm{D}$ printing and micropatterning.

Hence, developing viable manufacturing methods to construct multilevel silk fibroin structures will become the focus of future research. For this purpose, tissue engineers and materials scientists should work together to create precise designs using environmentally-friendly processing techniques.

\section{ACKNOWLEDGMENTS}

The authors thank Instituto Tecnológico Metropolitano (ITM) for supporting Maria Elena Moncada with this research.

\section{CONFLICTS OF INTEREST}

The authors declare that there is no conflict of interest.

\section{REFERENCES}

[1] F. Mottaghitalab; H. Hosseinkhani; M. A. Shokrgozar; C. Mao; M. Yang; M. Farokhi, "Silk as a potential candidate for bone tissue engineering," J. Control. Release, vol. 215, pp. 112-128, Oct. 2015.

https://doi.org/10.1016/j.jconrel.2015.07.031

[2] M. Farokhi et al., "Silk fibroin/hydroxyapatite composites for bone tissue engineering," Biotechnol. Adv., vol. 36, no. 1, pp. 68-91, Jan. 2018.

https://doi.org/10.1016/j.biotechadv.2017.10.0 $\underline{01}$

[3] N. Sultana, Biodegradable Polymer Based Scaffolds for Bone Tissue Engineering. Springer, 2013. https://doi.org/10.1007/978-3642-34802-0

[4] L. Li et al., "Functionalized cell-free scaffolds for bone defect repair inspired by self-healing of bone fractures: A review and new perspectives," Mater. Sci. Eng. C, vol. 98. pp. 1241-1251, May. 2019.

https://doi.org/10.1016/j.msec.2019.01.075

[5] Q. Chen; C. Zhu; G. A. Thouas, "Progress and challenges in biomaterials used for bone tissue engineering: bioactive glasses and elastomeric composites," Prog. Biomater., vol. 1, no. 1, Sep. 2012. https://doi.org/10.1186/2194-0517-1-2

[6] H. Yi; F. Ur Rehman; C. Zhao; B. Liu; N. He, "Recent advances in nano scaffolds for bone repair," Bone Res., vol. 4, no. 16050, pp. 111, Dec. 2016.

https://doi.org/10.1038/boneres.2016.50

[7] M. Maksimović, "The roles of nanotechnology and internet of nano things in healthcare transformation," TecnoLógicas, vol. 20, no. 40, pp. 139-153, Sep. 2017. https://doi.org/10.22430/22565337.720

[8] Y. Liu; J. Lim; S.-H. Teoh, "Review: Development of clinically relevant scaffolds for vascularised bone tissue engineering," Biotechnol. Adv., vol. 31, no. 5, pp. 688-705, Sep. 2013.

https://doi.org/10.1016/j.biotechadv.2012.10.0 $\underline{03}$

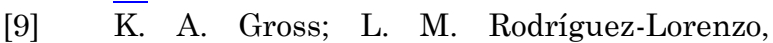
"Biodegradable composite scaffolds with an interconnected spherical network for bone tissue engineering," Biomaterials, vol. 25, no. 20, pp. 4955-4962,. Sep. 2004. 
https://doi.org/10.1016/j.biomaterials.2004.01 .046

[10] V. Olivier; N. Faucheux; P. Hardouin, "Biomaterial challenges and approaches to stem cell use in bone reconstructive surgery," Drug Discov. Today, vol. 9, no. 18, pp. 803811, Sep. 2004. https://doi.org/10.1016/S1359-6446(04)03222$\underline{2}$

[11] S. Sánchez-Salcedo; A. Nieto; M. Vallet-Regí; "Hydroxyapatite/B-tricalcium

hosphate/agarose macroporous scaffolds for bone tissue engineering," Chem. Eng. J., vol. 137, no. 1, pp. 62-71, Mar. 2008. https://doi.org/10.1016/j.cej.2007.09.011

[12] M. Wang, Surface Modification of Biomaterials and Tissue Engineering Scaffolds for Enhanced Osteoconductivity, in 3rd Kuala Lumpur International Conference on Biomedical Engineering 2006, vol. 15. Springer, 2007. https://doi.org/10.1007/978-3$\underline{540-68017-8}$

[13] J. A. Peres; T. Lamano, "Strategies for stimulation of new bone formation: a critical review," Braz. Dent. J., vol. 22, no. 6, pp. 443-448, Oct. 2011.

https://doi.org/10.1590/S0103.

64402011000600001

[14] B. F. Ricciardi; M. P. Bostrom, "Bone graft substitutes: Claims and credibility," Semin. Arthroplasty, vol. 24, no. 2, pp. 119-123, Jun. 2013.

https://doi.org/10.1053/j.sart.2013.07.002

[15] M. N. Rahaman et al., "Bioactive glass in tissue engineering," Acta Biomater., vol. 7, no. 6, pp. 2355-2373, Jun. 2011. https://doi.org/10.1016/j.actbio.2011.03.016

[16] S. Samavedi; A. R. Whittington; A. S. Goldstein, "Calcium phosphate ceramics in bone tissue engineering: A review of properties and their influence on cell behavior," Acta Biomater., vol. 9, no. 9, pp. 8037-8045, Sep. 2013.

https://doi.org/10.1016/j.actbio.2013.06.014

[17] Y. Kang; K. Kim; Y. Seol; S. Rhee, "Evaluations of osteogenic and osteoconductive properties of a non-woven silica gel fabric made by the electrospinning method," Acta Biomater., vol. 5, no. 1, pp. 462-469, Jan. 2009.

https://doi.org/10.1016/j.actbio.2008.07.004

[18] X. Qu et al., "The effect of oxygen plasma pretreatment and incubation in modified simulated body fluids on the formation of bone-like apatite on poly(lactide-co-glycolide) (70/30)," Biomaterials, vol. 28, no. 1, pp. 918, Jan. 2007.

https://doi.org/10.1016/j.biomaterials.2006.08 .024

[19] X. Fu; M. J. Jenkins; G. Sun; I. Bertoti; H.
Dong, "Characterization of active screen plasma modified polyurethane surfaces," Surf. Coatings Technol., vol. 206, no. 23, pp. 4799-4807, Jul. 2012.

https://doi.org/10.1016/j.surfcoat.2012.04.051

[20] G. Kumar; M. S. Waters; T. M. Farooque; M. F. Young; C. G. Simon, "Freeform fabricated scaffolds with roughened struts that enhance both stem cell proliferation and differentiation by controlling cell shape," Biomaterials, vol. 33, no. 16, pp. 4022-4030, Jun. 2012.

https://doi.org/10.1016/j.biomaterials.2012.02 .048

[21] A. Mata; E. J. Kim; C. A. Boehm; A. J. Fleischman; G. F. Muschler; S. Roy, "A three-dimensional scaffold with precise micro-architecture and surface microtextures," Biomaterials, vol. 30, no. 27, pp. 4610-4617, Sep. 2009.

https://doi.org/10.1016/j.biomaterials.2009.05 .023

[22] S. F. El-Amin et al., "Extracellular matrix production by human osteoblasts cultured on biodegradable polymers applicable for tissue engineering," Biomaterials, vol. 24, no. 7, pp. 1213-1221, Mar. 2003.

https://doi.org/10.1016/S0142-9612(02)00451$\underline{9}$

[23] S. Weeks; A. Kulkarni; H. Smith; C. Whittall; Y. Yang; J. Middleton, "The effects of chemokine, adhesion and extracellular matrix molecules on binding of mesenchymal stromal cells to poly(l-lactic acid)," Cytotherapy, vol. 14, no. 9, pp. 1080-1088, Sep. 2012. https://doi.org/10.3109/14653249.2012.70070 4

[24] N. Okutan; P. Terzi; F. Altay, "Affecting parameters on electrospinning process and characterization of electrospun gelatin nanofibers," Food Hydrocoll., vol. 39, pp. 1926, Aug. 2014.

https://doi.org/10.1016/j.foodhyd.2013.12.022

[25] S. Fakirov., Nano-size Polymers. Springer, 2016. https://doi.org/10.1007/978-3-319$\underline{39715-3}$

[26] B. Sun et al., "Advances in three-dimensional nanofibrous macrostructures via electrospinning," Prog. Polym. Sci., vol. 39, no. 5, pp. 862-890, May 2014. https://doi.org/10.1016/j.progpolymsci.2013.0 6.002

[27] S. Y. Park; C. S. Ki; Y. H. Park; H. M. Jung; K. M. Woo; H. J. Kim, "Electrospun Silk Fibroin Scaffolds with Macropores for Bone Regeneration: An In Vitro and In Vivo Study," Tissue Eng. Part A, vol. 16, no. 4, pp. 1271-1279, Jan. 2010.

https://doi.org/10.1089/ten.tea.2009.0328 
[28] E. J. Chong et al., "Evaluation of electrospun PCL/gelatin nanofibrous scaffold for wound healing and layered dermal reconstitution," Acta Biomater., vol. 3, no. 3, pp. 321-330, May. 2007.

https://doi.org/10.1016/j.actbio.2007.01.002

[29] D. Gaviria Arias; L. C. Caballero Mendez, "Uso de biomateriales a partir de la fibroína de la seda de gusano de seda (Bombyx mori L.) Para procesos de medicina regenerativa basada en ingeniería de tejidos," Rev. Médica Risaralda, vol. 21, no. 1, pp. 38-47, 2015. Disponible: URL

[30] D. Naskar; A. K. Ghosh; M. Manda; P. Das; S. K. Nandi; S. C. Kundu, "Dual growth factor loaded nonmulberry silk fibroin/carbon nanofiber composite 3D scaffolds for in vitro and in vivo bone regeneration," Biomaterials, vol. 136, pp. 67-85, Aug. 2017. https://doi.org/10.1016/j.biomaterials.2017.05 .014

[31] D. D. Zhang; L. X. Dai, "Preparation and characterization of electrospun poly(vinyl alcohol)/silk fibroin nanofibers as a potential drug delivery system," Adv. Mater. Res., vol. 709, pp. 215-220, Jun. 2013. https://doi.org/10.4028/www.scientific.net/A MR.709.215

[32] W. L. Li; J. J. Wang; L. X. Dai, "Preparation and Antibacterial Activity of Poly (vinyl Alcohol)/Silk Fibroin Composite Nanofibers Containing Silver Nanoparticles," $A d v$. Mater. Res., vol. 175-176, pp. 105-109, 2011. https://doi.org/10.4028/www.scientific.net/am r.175-176.105

[33] M. M. Pillai et al., "Silk-PVA Hybrid Nanofibrous Scaffolds for Enhanced Primary Human Meniscal Cell Proliferation," $J$. Membr. Biol., vol. 249, no. 6, pp. 813-822, 2016. https://doi.org/10.1007/s00232-0169932-z

[34] J. Jin; Y. Liu; C. Qin; J. Wang; L. Dai; K. Yamaura, "Electrospinning of regenerated silk fibroin and polyvinyl alcohol blended solution," J. Polym. Eng., vol. 30, no. 3-4, pp. 149-160, 2010.

https://doi.org/10.1515/POLYENG.2010.30.34.149

[35] M. M. Kalani; J. Nourmohammadi; B. Negahdari; A. Rahimi; S. A. Sell, "Electrospun core-sheath poly(vinyl alcohol)/silk fibroin nanofibers with Rosuvastatin release functionality for enhancing osteogenesis of human adiposederived stem cells," Mater. Sci. Eng. C, vol. 99, pp. 129-139, Jun. 2019. https://doi.org/10.1016/j.msec.2019.01.100

[36] H. J. Cho; Y. J. Yoo; J. W. Kim; Y. H. Park; D. G. Bae; I. C. Um, "Effect of molecular weight and storage time on the wet- and electro-spinning of regenerated silk fibroin," Polym. Degrad. Stab., vol. 97, no. 6, pp. 1060-1066, Jun. 2012.

https://doi.org/10.1016/j.polymdegradstab.20 12.03.007

[37] S. Calamak; E. A. Aksoy; C. Erdogdu; M. Sagiroglu; K. Ulubayram, "Silver nanoparticle containing silk fibroin bionanotextiles," J. Nanoparticle Res., vol. 17, no. 2, Feb. 2015.

https://doi.org/10.1007/s11051-015-2895-7

[38] J. Zhu; H. Shao; X. Hu, "Morphology and structure of electrospun mats from regenerated silk fibroin aqueous solutions with adjusting $\mathrm{pH}$," Int. J. Biol. Macromol., vol. 41, no. 4, pp. 469-474, Oct. 2007. https://doi.org/10.1016/j.ijbiomac.2007.06.006

[39] S. Sukigara; M. Gandhi; J. Ayutsede; M. Micklus; F. Ko, "Regeneration of Bombyx mori silk by electrospinning-part 1: processing parameters and geometric properties," Polymer., vol. 44, no. 19, pp. 5721-5727, Sep. 2003.

https://doi.org/10.1016/S0032-3861(03)00532$\underline{9}$

[40] S. Sohn; S. P. Gido, "Wet-Spinning of Osmotically Stressed Silk Fibroin," Biomacromolecules, vol. 10, no. 8, pp. 20862091, Aug. 2009.

https://doi.org/10.1021/bm900169z

[41] F. Zhang et al., "Mechanisms and Control of Silk-Based Electrospinning," Biomacromolecules, vol. 13, no. 3, pp. 798804, Feb. 2012. https://doi.org/10.1021/bm201719s

[42] C. Meechaisue et al., "Preparation of electrospun silk fibroin fiber mats as bone scaffolds: a preliminary study," Biomed. Mater., vol. 2, no. 3, pp. 181-188, Sep. 2007. https://doi.org/10.1088/1748-6041/2/3/003

[43] J. Ayutsede; M. Gandhi; S. Sukigara; M. Micklus; H.-E. Chen; F. Ko, "Regeneration of Bombyx mori silk by electrospinning. Part 3: characterization of electrospun nonwoven mat," Polymer., vol. 46, no. 5, pp. 1625-1634, Feb. 2005.

https://doi.org/10.1016/j.polymer.2004.11.029

[44] S. H. Kim; Y. S. Nam; T. S. Lee; W. H. Park, "Silk Fibroin Nanofiber. Electrospinning, Properties, and Structure," Polym. J., vol. 35, pp. 185-190, Feb. 2003.

https://doi.org/10.1295/polymj.35.185

[45] J. H. Kim et al., "Preparation and in vivo degradation of controlled biodegradability of electrospun silk fibroin nanofiber mats," $J$. Biomed. Mater. Res. Part A, vol. 100A, no. 12 , pp. 3287-3295, Dec. 2012. https://doi.org/10.1002/jbm.a.34274

[46] C. S. Ki et al., "Development of 3-D nanofibrous fibroin scaffold with high 
porosity by electrospinning: implications for bone regeneration," Biotechnol. Lett., vol. 30, no. 3, pp. 405-410, Mar. 2008. https://doi.org/10.1007/s10529-007-9581-5

[47] N. Haghighipour; Z. Hadisi; J. Nourmohammadi; S. Heidari, "How direct electrospinning in methanol bath affects the physico-chemical and biological properties of silk fibroin nanofibrous scaffolds," Micro Nano Lett., vol. 11, no. 9, pp. 514-517, Sep. 2016. https://doi.org/10.1049/mnl.2016.0301

[48] K.-H. Kim et al., "Biological efficacy of silk fibroin nanofiber membranes for guided bone regeneration," J. Biotechnol., vol. 120, no. 3, pp. 327-339, Nov. 2005. https://doi.org/10.1016/j.jbiotec.2005.06.033

[49] N. Panda; A. Bissoyi; K. Pramanik; A. Biswas, "Development of novel electrospun nanofibrous scaffold from $\mathrm{P}$. ricini and $\mathrm{A}$. mylitta silk fibroin blend with improved surface and biological properties," Mater. Sci. Eng. C, vol. 48, pp. 521-532, Mar. 2015. https://doi.org/10.1016/j.msec.2014.12.010

[50] C. Li; C. Vepari; H.-J. Jin; H. J. Kim; D. L. Kaplan, "Electrospun silk-BMP-2 scaffolds for bone tissue engineering," Biomaterials, vol. 27, no. 16, pp. 3115-3124, Jun. 2006. https://doi.org/10.1016/j.biomaterials.2006.01 .022

[51] R. R. Jose; R. Elia; M. A. Firpo; D. L. Kaplan; R. A. Peattie, "Seamless, axially aligned, fiber tubes, meshes, microbundles and gradient biomaterial constructs," $J$. Mater. Sci. Mater. Med., vol. 23, no. 11, pp. 2679-2695, Nov. 2012. https://doi.org/10.1007/s10856-012-4739-7

[52] R. Serôdio et al., "Ultrasound sonication prior to electrospinning tailors silk fibroin/PEO membranes for periodontal regeneration," Mater. Sci. Eng. C, vol. 98, no. 2018, pp. 969-981, May. 2019. https://doi.org/10.1016/j.msec.2019.01.055

[53] Y. Kishimoto; H. Morikawa; S. Yamanaka; Y. Tamada, "Electrospinning of silk fibroin from all aqueous solution at low concentration," Mater. Sci. Eng. C, vol. 73, pp. 498-506, Apr. 2017.

https://doi.org/10.1016/j.msec.2016.12.113

[54] C. Li; H.-J. Jin; G. D. Botsaris; D. L. Kaplan, "Silk apatite composites from electrospun fibers," J. Mater. Res., vol. 20, no. 12, pp. 3374-3384, Dec. 2005. https://doi.org/10.1557/jmr.2005.0425

[55] J. Song et al., "Electrospun Nanofibrous Silk Fibroin Membranes Containing Gelatin Nanospheres for Controlled Delivery of Biomolecules," Adv. Healthc. Mater., vol. 6, no. 14, p. 1700014, Jul. 2017. https://doi.org/10.1002/adhm.201700014

[56] M. Gandhi; H. Yang; L. Shor; F. Ko, "Post- spinning modification of electrospun nanofiber nanocomposite from Bombyx mori silk and carbon nanotubes," Polymer., vol. 50, no. 8, pp. 1918-1924, Apr. 2009. https://doi.org/10.1016/j.polymer.2009.02.022

[57] M. Gholipourmalekabadi et al., "Optimization of nanofibrous silk fibroin scaffold as a delivery system for bone marrow adherent cells: in vitro and in vivo studies," Biotechnol. Appl. Biochem., vol. 62, no. 6, pp. 785-794, Nov. 2015. https://doi.org/10.1002/bab.1324

[58] K. Ohgo; C. Zhao; M. Kobayashi; T. Asakura, "Preparation of non-woven nanofibers of Bombyx mori silk, Samia cynthia ricini silk and recombinant hybrid silk with electrospinning method," Polymer., vol. 44, no. 3, pp. 841-846, Jan. 2003. https://doi.org/10.1016/S0032-3861(02)00819$\underline{4}$

[59] C. M. Srivastava; R. Purwar; A. P. Gupta, "Enhanced potential of biomimetic, silver nanoparticles functionalized Antheraea mylitta (tasar) silk fibroin nanofibrous mats for skin tissue engineering," Int. J. Biol. Macromol., vol. 130, pp. 437-453, Jun. 2019. https://doi.org/10.1016/j.ijbiomac.2018.12.255

[60] B. Niu; B. Li; Y. Gu; X. Shen; Y. Liu; L. Chen, "In vitro evaluation of electrospun silk fibroin/nano-hydroxyapatite/BMP-2 scaffolds for bone regeneration," J. Biomater. Sci. Polym. Ed., vol. 28, no. 3, pp. 257-270, Feb. 2017. https://doi.org/10.1080/09205063.2016.12621 $\underline{63}$

[61] $\quad \frac{63}{Z}$ Hadisi; J. Nourmohammadi; J. Mohammadi, "Composite of porous starchsilk fibroin nanofiber-calcium phosphate for bone regeneration," Ceram. Int., vol. 41, no. 9, pp. 10745-10754, Nov. 2015. https://doi.org/10.1016/j.ceramint.2015.05.01 $\underline{0}$

[62] K. Wei et al., "Fabrication of nanohydroxyapatite on electrospun silk fibroin nanofiber and their effects in osteoblastic behavior," J. Biomed. Mater. Res. Part A, vol. 97A, no. 3, pp. 272-280, Jun. 2011. https://doi.org/10.1002/jbm.a.33054

[63] H. Ding et al., "Establishment of 3D culture and induction of osteogenic differentiation of pre-osteoblasts using wet-collected aligned scaffolds," Mater. Sci. Eng. C, vol. 71, pp. 222-230, Feb. 2017.

https://doi.org/10.1016/j.msec.2016.10.002

[64] G. Griffanti; M. James-Bhasin; I. Donelli; G. Freddi; S. N. Nazhat, "Functionalization of silk fibroin through anionic fibroin derived polypeptides," Biomed. Mater., vol. 14, no. 1, Nov. 2018. Available: URL

[65] S. Çalamak; C. Erdoğdu; M. Özalp; K. 
Ulubayram, "Silk fibroin based antibacterial bionanotextiles as wound dressing materials," Mater. Sci. Eng. C, vol. 43, pp. 11-20, Oct. 2014.

https://doi.org/10.1016/j.msec.2014.07.001

[66] R. Liu; J. Ming; H. Zhang; B. Zuo, "EDC/NHS crosslinked electrospun regenerated tussah silk fibroin nanofiber mats," Fibers Polym., vol. 13, no. 5, pp. 613617, May 2012.

https://doi.org/10.1007/s12221-012-0613-y

[67] S. Mohammadzadehmoghadam; Y. Dong, "Fabrication and Characterization of Electrospun Silk Fibroin/Gelatin Scaffolds Crosslinked With Glutaraldehyde Vapor," Front. Mater., vol. 6, no. 91, May, pp. 1-12, May. 2019.

https://doi.org/10.3389/fmats.2019.00091

[68] A. Gaviria; S. Sanchez-Diaz; A. Ríos; M. S. Peresin; A. Restrepo-Osorio, "Silk fibroin from silk fibrous waste: characterization and electrospinning," IOP Conf. Ser. Mater. Sci. Eng., vol. 254, no. 10, p. 102005, Oct. 2017. https://doi.org/10.1088/1757899X/254/10/102005

[69] J. Zhou; C. Cao; Ma, "A novel threedimensional tubular scaffold prepared from silk fibroin by electrospinning," Int. J. Biol. Macromol., vol. 45, no. 5, pp. 504-510, Dec. 2009.

https://doi.org/10.1016/j.ijbiomac.2009.09.006

[70] M. Andiyappan; S. Sundaramoorthy; P. Vidyasekar; N. T. Srinivasan; R. S. Verma, "Characterization of electrospun fibrous scaffold produced from Indian eri silk fibroin," Int. J. Mater. Res., vol. 104, no. 5, pp. 498-506, May. 2013.

https://doi.org/10.3139/146.110888

[71] I. C. Um; C. S. Ki; H. Kweon; K. G. Lee; D. W. Ihm; Y. H. Park, "Wet spinning of silk polymer: II. Effect of drawing on the structural characteristics and properties of filament," Int. J. Biol. Macromol., vol. 34, no. 1-2, pp. 107-119, Apr. 2004.

https://doi.org/10.1016/j.ijbiomac.2004.03.011

[72] J. S. Ko; K. H. Lee; D. G. Bae; I. C. Um, "Miscibility, structural characteristics, and thermal behavior of wet spun regenerated silk fibroin/nylon 6 blend filaments," Fibers Polym., vol. 11, no. 1, pp. 14-20, Feb. 2010. https://doi.org/10.1007/s12221-010-0014-z

[73] M. Buitrago-Vásquez; C. P. Ossa-Orozco, "Degradation, water uptake, injectability and mechanical strength of injectable bone substitutes composed of silk fibroin and hydroxyapatite nanorods," Rev. Fac. Ing., vol. 27, no. 48, pp. 49-60, 2018. https://doi.org/10.19053/01211129.v27.n48.20 $\underline{18.8072}$

[74] J. Ming; B. Zuo, "A novel electrospun silk fibroin/hydroxyapatite hybrid nanofibers," Mater. Chem. Phys., vol. 137, no. 1, pp. 421427, Nov. 2012.

https://doi.org/10.1016/j.matchemphys.2012.1 $\underline{0.001}$

[75] J.-P. Chen; S.-H. Chen; G.-J. Lai, "Preparation and characterization of biomimetic silk fibroin/chitosan composite nanofibers by electrospinning for osteoblasts culture," Nanoscale Res. Lett., vol. 7, no. 1, p. 170, Dec. 2012. https://doi.org/10.1186/1556276X-7-170

[76] Y. Yang; X. Ding; T. Zou; G. Peng; H. Liu; Y. Fan, "Preparation and characterization of electrospun graphene/silk fibroin conductive fibrous scaffolds," $R S C A d v$, vol. 7, no. 13, pp. 7954-7963, 2017.

https://doi.org/10.1039/C6RA26807B

[77] F. A. Sheikh et al., "A novel approach to fabricate silk nanofibers containing hydroxyapatite nanoparticles using a threeway stopcock connector," Nanoscale Res. Lett., vol. 8, no. 1, p. 303, Dec. 2013. https://doi.org/10.1186/1556-276X-8-303

[78] H. Nalvuran; A. E. Elçin; Y. M. Elçin, "Nanofibrous silk fibroin/reduced graphene oxide scaffolds for tissue engineering and cell culture applications," Int. J. Biol. Macromol., vol. 114, pp. 77-84, Jul. 2018. https://doi.org/10.1016/j.ijbiomac.2018.03.072

[79] N. Panda; A. Bissoyi; K. Pramanik; A. Biswas, "Directing osteogenesis of stem cells with hydroxyapatite precipitated electrospun eri-tasar silk fibroin nanofibrous scaffold," $J$. Biomater. Sci. Polym. Ed., vol. 25, no. 13, pp. 1440-1457, Sep. 2014.

https://doi.org/10.1080/09205063.2014.94354 $\underline{8}$

[80] M. Buitrago Vásquez, "Degradación, absorción, inyectabilidad y resistencia mecánica de sustitutos óseos inyectables compuestos de fibroína y nanobarras de hidroxiapatita," Rev. Fac. ing. vol. 27, no. 48, pp.49-60 2017.

http://dx.doi.org/10.19053/01211129.v27.n48. 2018.8072

[81] M. Andiappan et al., "Electrospun eri silk fibroin scaffold coated with hydroxyapatite for bone tissue engineering applications," Prog. Biomater., vol. 2, no. 1, p. 6, 2013. https://doi.org/10.1186/2194-0517-2-6

[82] S. Calamak; E. A. Aksoy; N. Ertas; C. Erdogdu, M. Sagiroglu; K. Ulubayram, "Ag/silk fibroin nanofibers: Effect of fibroin morphology on Ag+ release and antibacterial activity," Eur. Polym. J., vol. 67, pp. 99-112, Jun. 2015

https://doi.org/10.1016/j.eurpolymj.2015.03.0 $\underline{68}$

[83] N. N. Panda; A. Biswas; K. Pramanik; S. 
Jonnalagadda, "Enhanced osteogenic potential of human mesenchymal stem cells on electrospun nanofibrous scaffolds prepared from eri-tasar silk fibroin," $J$. Biomed. Mater. Res. Part B Appl. Biomater., vol. 103, no. 5, pp. 971-982, Jul. 2015. https://doi.org/10.1002/jbm.b.33272

[84] H. JoonJin; J. Chen; V. Karageorgiou; G. H. Altman; D. L. Kaplan, "Human bone marrow stromal cell responses on electrospun silk fibroin mats," Biomaterials, vol. 25, no. 6, pp. 1039-1047, Mar. 2004. https://doi.org/10.1016/S0142-9612(03)00609$\underline{4}$

[85] H. Kim; L. Che; Y. Ha; W. Ryu, "Mechanically-reinforced electrospun composite silk fibroin nanofibers containing hydroxyapatite nanoparticles," Mater. Sci. Eng. C, vol. 40, pp. 324-335, Jul. 2014. https://doi.org/10.1016/j.msec.2014.04.012

[86] M. Kang; P. Chen; H.-J. Jin, "Preparation of multiwalled carbon nanotubes incorporated silk fibroin nanofibers by electrospinning," Curr. Appl. Phys., vol. 9, no. 1, pp. S95-S97, Jan. 2009.

https://doi.org/10.1016/j.cap.2008.08.014

[87] V. Karageorgiou; D. Kaplan, "Porosity of 3D biomaterial scaffolds and osteogenesis," Biomaterials, vol. 26, no. 27, pp. 5474-5491, Sep. 2005.

https://doi.org/10.1016/j.biomaterials.2005.02 $\underline{.002}$

\section{AUTHOR CONTRIBUTIONS}

Co-directed the research project and chose the methods implemented. They determined the methodology, and prepared the figures and tables. They revised the manuscript, corrected the writing style, and improved the article in the different sections.

(D) 2 Co-directed the research project and chose the methods implemented. They determined the methodology, and prepared the figures and tables. They revised the manuscript, corrected the writing style, and improved the article in the different sections.

(i) 3 Worked actively (leading) the writtening in the different sections of the research article and she worked in the analysis of the results, discussion, and conclusions. 